\title{
Bank Risk Within and Across Equilibria
}


Bank Risk Within and Across Equilibria

Itai Agur 


\title{
IMF Working Paper
}

IMF - Singapore Regional Training Institute

\section{Bank Risk Within and Across Equilibria ${ }^{1}$}

Prepared by Itai Agur

Authorized for distribution by Sunil Sharma

July 2014

\section{This Working Paper should not be reported as representing the views of the IMF.} The views expressed in this Working Paper are those of the author(s) and do not necessarily represent those of the IMF or IMF policy. Working Papers describe research in progress by the author(s) and are published to elicit comments and to further debate.

\begin{abstract}
The global financial crisis highlighted that the financial system can be most vulnerable when it seems most stable. This paper models non-linear dynamics in banking. Small shocks can lead from an equilibrium with few bank defaults straight to a full freeze. The mechanism is based on amplification between adverse selection on banks' funding market and moral hazard in bank monitoring. Our results imply trade-offs between regulators' microprudential desire to shield individual weak banks and the macroprudential consequences of doing so. Moreover, limiting bank reliance on wholesale funding always reduces systemic risk, but limiting the correlation between bank portfolios does not.
\end{abstract}

JEL Classification Numbers: G01, G21

Keywords: Bank risk, Wholesale funding, Adverse selection, Multiple equilibria, Liquidity Author's E-Mail Address:iagur@imf.org

\footnotetext{
${ }^{1}$ This paper is forthcoming in the Journal of Banking and Finance. Part of the work for this paper was done when the author was employed by the Research Department of the Dutch Central Bank (DNB). The disclaimer also applies to DNB. I am grateful to Enrico Perotti, Charles Calomiris, Eric van Wincoop, Viral Acharya, Xavier Freixas, Luc Laeven, Enrique Mendoza, Chen Zhou, Maria Demertzis, Razvan Vlahu, Christian Castro, Roland Meeks and Iman van Lelyveld and to audiences at DNB, the Bank of England and the 2012 Australasian Finance and Banking Conference for comments.
} 


\section{Contents}

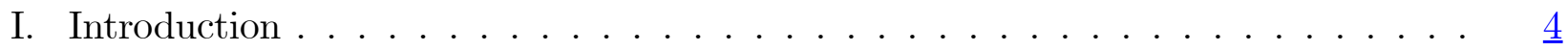

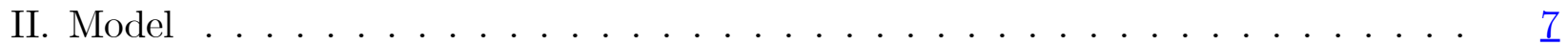

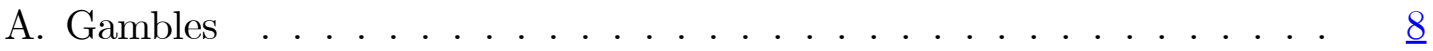

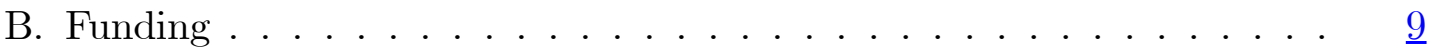

C. Bank maximization . . . . . . . . . . . . . . . 10

D. Breakdown threshold . . . . . . . . . . . . . . . . 11

E. Reaction function . . . . . . . . . . . . . . . . . 12

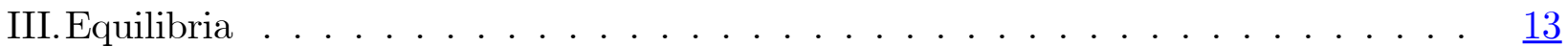

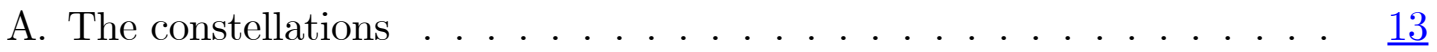

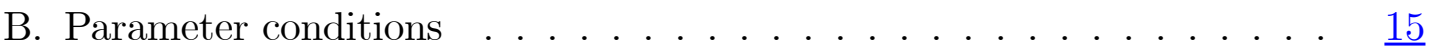

IV.Numerical examples . . . . . . . . . . . . . . . . . . 16

A. An example of Case II . . . . . . . . . . . . . . . . . 17

B. An example of Case III . . . . . . . . . . . . . . . . . . 17

C. Endogenous breakdown threshold . . . . . . . . . . . . . 18

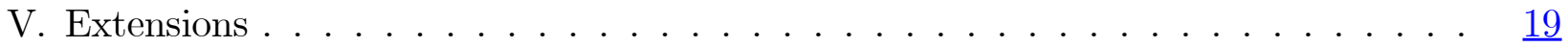

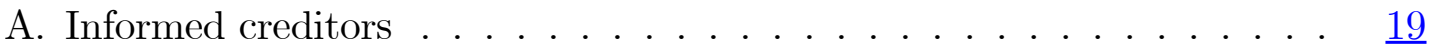

B. Idiosyncratic bank soundness . . . . . . . . . . . $\underline{20}$

C. Retail depositors . . . . . . . . . . . . . . . . . . . . $\underline{22}$

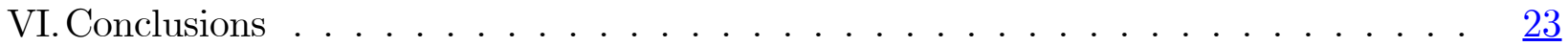

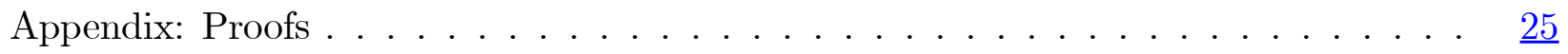

References .......................... . . $\underline{31}$

Tables

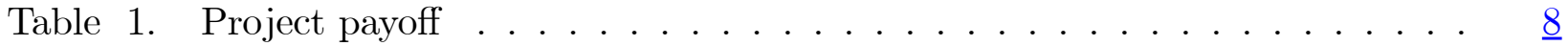

Table 2. Timing of the game ................. $\underline{9}$

Table 3. Timing of the game with creditor information . . . . . . . . $\underline{19}$

Figures

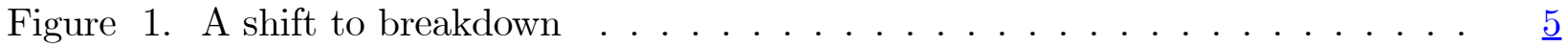

Figure 2. Low-end corner only . . . . . . . . . . . . . . . . 14

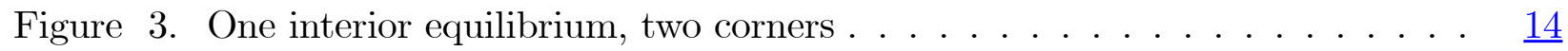

Figure 4 . Two interior equilibria . . . . . . . . . . . . . . 15

Figure 5. The effects of falling returns $\ldots \ldots \ldots \ldots \ldots \ldots$

Figure 6. From Case II to Case I . . . . . . . . . . . . . . . . 17

Figure 7 . From Case III to Case I . . . . . . . . . . . . . . . . . . . . $\underline{18}$ 
Figure 8. Breakdown threshold shift . . . . . . . . . . . . . . $\underline{19}$ 


\section{Introduction}

The market for subprime mortgages formed only a fraction of banks' total exposures. Yet, its meltdown brought the entire sector to its knees and led, in particular, to a protracted freeze on banks' funding market. How can a financial system seem so stable, with low default rates and low funding costs, and simultaneously be so vulnerable to shocks? This paper provides a model to differentiate between the concepts of risk within an equilibrium (individual bank default risk) and across equilibria (the likelihood that a shock leads to market breakdown). It shows that risk within and across equilibria can move in opposite directions and that it is possible for default rates to be lowest when the system as a whole is most sensitive to shocks.

The mechanism is based on mutually reinforcing effects between an individual bank's risk taking and the extent of asymmetric information on the wholesale market for unsecured bank funding. That market is plagued by adverse selection as both banks that have genuine liquidity shortfalls and those that are insolvent but want to gamble for resurrection demand funds. Although financiers do not know the soundness of a given bank, they do know the probability that they face a sound bank. This generates a type of prisoners' dilemma among banks. Collectively they would do well to limit risk taking, because by reducing the share of unsound banks on the market, they can lower the adverse selection premia that they have to pay for their funding. However, each individual bank does not internalize how its risk taking affects aggregate premia, and therefore takes too much risk. The externalities that banks impose on each other are the root of moral hazard in our model.

The extent of externalities and the depth of asymmetric information problems reinforce each other. When banks have greater incentives to take risk, adverse selection premia on their funding market increase. And the higher are banks' funding costs, the greater are their incentives to take risk. This comes about through a charter value effect: when funding is more expensive, banks' equity is worth less, and they are more inclined to play risky strategies that pay off much if successful, but externalize most losses to creditors if unsuccessful. Both of these channels are quite well established in the literature. The idea that bank risk feeds into risk premia on the unsecured funding market is modelled by Freixas, Parigi and Rochet (2004) and Heider, Hoerova and Holthausen (2009). And the effect of charter values on bank risk has been a common feature in the banking literature since Keeley (1990). It is the combination of the channels that is new to the paper, and that sparks non-linear reactions in the model. An example of the game dynamics is given in figure 1 . 


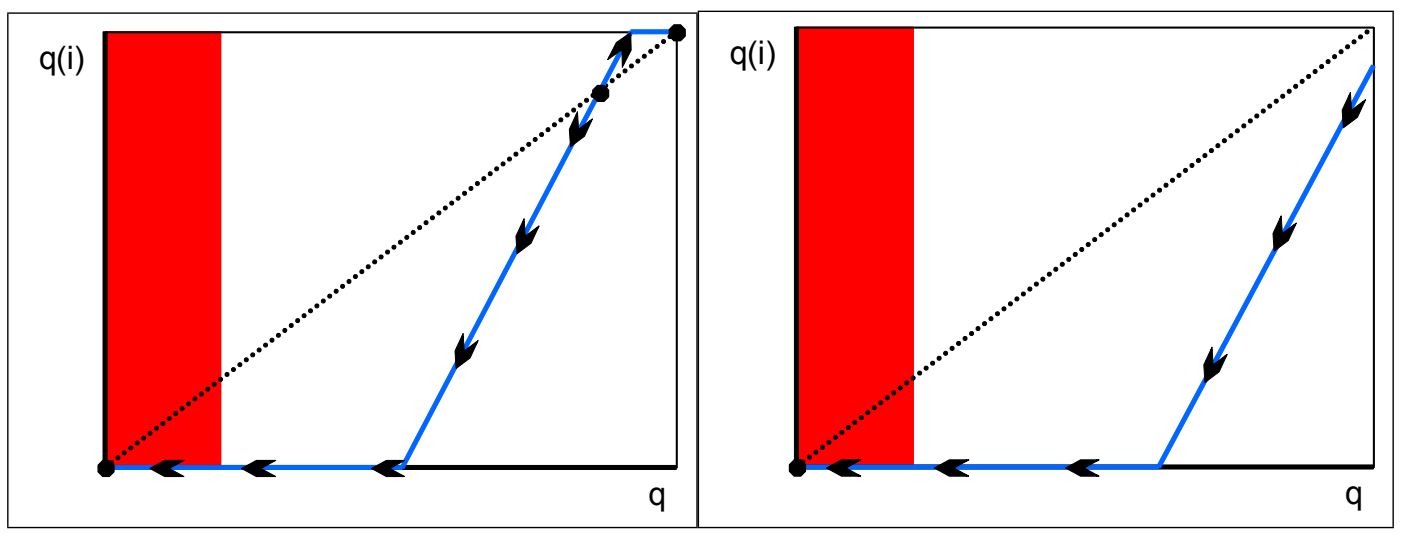

Figure 1: A shift to breakdown

In this figure a bank's optimal decision on $q_{i}$ (which is monitoring effort, the inverse of risk taking) is a strategic complement to the optimal decision of other banks, q. An interior Nash equilibrium occurs where the reaction function crosses the 45 degree line, as depicted in the left panel of the figure. At this point no bank deviates, given the play of other banks. Outside of the interior equilibrium the arrows portray the direction of play, which evolves towards the corners. Three equilibria thus coexist in the left panel: one interior, and two corners. The shaded area represents the "breakdown zone", where adverse selection problems are so severe that the funding market freezes, because there exists no interest rate at which financiers are willing to provide loans, just like in Akerlof's (1970) market for lemons.

The difference between the left and the right panels of figure 1 captures our main story. Initially, the financial sector can be at one of the "good" equilibria in the left panel, namely the interior equilibrium or the top-right corner, where individual bank default risk is small or zero. However, it does not take a large parameter shock - such as a decline in asset returns - to push the reaction function beyond the 45 degree line, where the breakdown equilibrium is unique. This is shown in the right panel, and summarizes the result of our main model.

We investigate three additional dimensions in extensions of the model. First, we provide creditors with an imperfect source of information about individual bank quality. Varying the degree of this creditor information, we show that banks' concern that their true quality will be uncovered, makes them raise monitoring effort ex-ante, reducing the likelihood of funding market breakdown. Subsequently, we introduce idiosyncratic risk in bank portfolios and vary its size as compared to the common exposures. Greater correlation between bank portfolios has various effects in our model and the relation between this correlation and systemic risk is intricate. Finally, we introduce retail depositors into the model and find that less reliance on wholesale funding reduces the vulnerability of the funding market.

Our paper relates to three strands of literature on bank risk and its regulation. Firstly, the literature analyzing the trade-offs between micro- and macroprudential regulation. Secondly, the research on the vulnerabilities inherent in banks' wholesale funding market. And, thirdly, the literature on the risks emanating from multiple equilibria in banking.

The global financial crisis has given rise to a rapidly expanding literature on systemic risk 
and the macroprudential regulation designed to rein it in. ${ }^{1}$ Microprudential regulation differs from macroprudential regulation in terms of objectives, namely safeguarding the health of individual institutions versus the system as whole. An important question is to what extent there are trade-offs between achieving those micro- and macroprudential objectives. A subset of the macroprudential literature focusses on analyzing this trade-off. Acharya (2009) shows that microprudential regulation induces banks to hoard on aggregate risk, because this regulation fails to mitigate the incentives of banks to shift risks to the system through their own limited liability. ${ }^{2}$ In similar vein, Ibragimov, Jaffee and Walden (2010) and Zhou (2013) both show that capital requirements can induce banks to individually become less diversified, raising common exposures and thereby systemic risk. Thus, the most common microprudential tool backfires from a macroprudential perspective. However, this is nuanced by the result of Wagner (2010) that diversification at the individual bank level can actually raise systemic risk, similarly to the result from our extension. In Perotti, Ratnovski and Vlahu (2011) capital requirements backfire through a different mechanism, namely by raising tail risks. The financial crisis has highlighted that it is particularly in these tails that bank exposures are correlated.

In contrast to the above mentioned papers, which focus on systemic risk on banks' asset side, our paper highlights the micro- versus macroprudential trade-off from the perspective of banks' funding market. Another paper that does so is Eichberger and Summer (2005), within the context of interbank contagion. In their model domino effects imply that one bank's failure can knock on to the rest of the system. Eichberger and Summer (2005) show that raising capital requirements can, at times, worsen the risk of an interbank cascade. ${ }^{3}$ Ratnovski (2013) shows that liquidity regulation can make banks pursue opacity. If liquidity regulation is not supplemented with rules for transparency, regulation can fail to reduce systemic risk. In contrast to these papers, our mechanism is instead based on the interaction of banks' strategic decisions when their funding market is plagued by adverse selection.

The second literature to which our paper relates is on the analysis of the wholesale funding market. There is a sizeable literature on the potential inefficiencies and risks associated to this market. 4 The modeling approach used in this paper is most closely related to Freixas, Parigi and Rochet (2004) and Heider, Hoerova and Holthausen (2009). Freixas, Parigi and Rochet (2004) model the adverse selection that arises when insolvency and illiquidity are

\footnotetext{
${ }^{1}$ See, among others, Brunnermeier and others (2009), Claessens and others (2010), Lim and others. (2011), Arnold and others (2012), Galati and Moessner (2012), Agur and Sharma (2013) and Borio (2014).

${ }^{2}$ A related result is found by Acharya and Yorulmazer (2007) for the case of bailout policy. The bailout policy of a microprudential regulator that focuses on individual banks provides ex-ante incentives for banks to herd so that they are more likely to fail simultaneously.

${ }^{3}$ Several papers model and measure the potential for such interbank cascades. See, among others, Furfine (2003), Nier and others (2007), Aikman and others (2009), Allen and Babus (2010), Liedorp and others (2010), Upper (2011), Battiston and others (2012), Georg (2013), Glasserman and Young (2014) and Garratt, Mahadeva and Svirydzenka (2014).

${ }^{4}$ See Bhattacharya and Gale (1987), Rochet and Tirole (1996), Flannery (1996), Allen and Gale (2000), Freixas, Parigi and Rochet (2000), Rochet and Vives (2004), Freixas and Jorge (2008), Allen, Carletti and Gale (2009), Heider and Hoerova (2009), Freixas, Martin and Skeie (2011), Huang and Ratnovksi (2011), Fecht, Grüner and Hartmann (2012), Acharya, Gromb and Yorulmazer (2012), Anand, Gai and Marsili (2012), Ennis and Weinberg (2013) and Castiglionesi and Wagner (2013).
} 
indistinguishable to banks' financiers. They show that Lender of Last Resort intervention can be efficient given this information asymmetry. Heider, Hoerova and Holthausen (2009) model an interbank market in which not only borrowing but also lending by banks is endogenous. They identify three regimes: one with full participation; another where adverse selection causes the best quality borrowers leave; and the last regime involves liquidity hoarding and market breakdown. The difference to our paper is that bank risk taking and solvency are exogenous in these models. Hence credit risk premia do not feed back into the decisions of banks, and the type of effects we analyze do not arise.

The third literature to which our paper relates is on the potential risks associated to multiple equilibria in banking. The multiplicity of equilibria has been a common feature of the banking literature since Diamond and Dybvig (1983). However, in most of the existing banking literature on multiple equilibria, the triggers that move banks from one equilibrium to another go unmodelled. In our model shifts between equilibria can be related to parameters, which makes it possible to discuss the size of a shock needed to induce an equilibrium shift. One other paper that relates shifts between banking equilibria to parameter shocks is Goldstein and Pauzner (2005), who use a global games technique to solve for a unique equilibrium. Instead of a parameter shock, it also possible for an institutional change, such as international financial integration, to trigger an equilibrium shift. This is modelled by Freixas and Holthausen (2005) and Boissay (2011). Furthermore, our model is new to the banking literature in that it distinguishes between stable and unstable equilibria, which are key features of non-linear modelling (Rosser, 1999).

\section{Model}

We assume a mass of identical, risk-neutral banks, indexed by $i \in[0,1]$, whose asset side initially consists of one project. That project yields a total return $R>1$ if it succeeds. Whether the project succeeds depends on its funding and the behavior of its entrepreneur. Firstly, the project needs a certain amount of funding to be of any value. One can think of this as fixed development costs on the part of the project's entrepreneur, who can only make his business profitable if he receives a minimum amount of initial capital, which is 1 . If the bank provides the project with funding less than this amount then the best the entrepreneur can do is invest the principal in a risk-free technology which yields zero net return.

Secondly, the bank faces the risk that the entrepreneur runs off with the money without developing the project at all. That is, the entrepreneur shirks. To prevent this from happening the bank must exert monitoring effort, $q_{i} \in[0,1]$, with associated non-pecuniary cost

$c q_{i}^{2}, c \geq 0$ experienced by bank management. We assume that the probability of making the entrepreneur work on the project is directly proportional to this monitoring effort. In particular, we say that $q_{i}$ is the probability of the bank possessing a "sound" - that is, potentially valuable - project. With probability $1-q_{i}$ bank monitoring fails, the entrepreneur shirks and the project is unsound, and therefore certain to be of no value, regardless of the amount invested in it. In section 5B we provide an extension in which this probability also depends on idiosyncratic features and not only on bank monitoring.

(C)International Monetary Fund. Not for Redistribution 
For simplicity we will refer to sound-project banks as "sound banks" and unsound-project banks as "unsound banks". Overall, the gross payoff structure of the project looks as follows:

\begin{tabular}{|l|c|c|}
\hline & Unsound quality & Sound quality \\
\hline Funding $<1$ & 0 & $1 *($ funding $)$ \\
\hline Funding 1 & 0 & $R *($ funding $)=R$ \\
\hline
\end{tabular}

Table 1: Project payoff

The realization of project soundness is private knowledge revealed only to the bank: only the bank's loan officers can observe whether the project's entrepreneur has shirked or not. It is the combination of funding needs and the inability of outsiders to distinguish between banks with sound and unsound projects that forms the basis of the adverse selection problem in our model. The idea that a sound project loses value under funding difficulties relates to the broader notion of fire sales (Shleifer and Vishny, 2011) and forced early termination (Diamond and Dybvig, 1983). That unsound banks have an appetite for funding, in spite of the fact that their initial project is worthless, is because of the possibility to invest the funds in a risky gamble. They can "gamble for resurrection" because they have nothing to lose if the gamble fails, but everything to gain on the upside.

\section{A. Gambles}

Banks have the possibility of investing an amount between 0 and 1 in a gamble after observing the soundness of their project. If successful then the gamble multiplies the amount invested in it by $x$, but if unsuccessful then the funds invested in the gamble are lost. The probability that it succeeds is $\rho$, where $0<\rho<\frac{1}{x}$. Thus, the gamble has a negative present value: it destroys value because the expected payoff is smaller than the principal invested $(\rho x<1)$.

Naturally, creditors (whose precise role is discussed below) will take this into consideration ex-ante and no lending would ever occur to a bank that is known to gamble. That is, there exists no interest rate at which a financier is willing to lend to a gambling bank. Since a bank is protected by limited liability upon default, the most financiers could request is to be paid the entire proceeds of the gamble if it succeeds, namely $x$. But even at an interest rate $r=x$ the expected gross return on a loan to the bank is $\rho r=\rho x<1$ : the loan is loss-making in expectation. However, because of the information asymmetry, when sound banks use the borrowed funds productively then they cross-subsidize the gambles of unsound banks, and hence gambles can occur in equilibrium. 


\section{B. Funding}

\begin{tabular}{|l|}
\hline \multicolumn{1}{|c|}{ Stage } \\
\hline 1. Banks set monitoring effort \\
\hline 2. Project soundness realizes \\
\hline 3. Banks decide on gambles \\
\hline 4. Bank funding \\
\hline 5. Projects and gambles pay out \\
\hline
\end{tabular}

Table 2: Timing of the game

As shown in table 2, we model banks' funding stage as occurring after the asset side stages. This is important for our setup because banks must first be sorted into types (on project quality and gambles) before they turn to the funding market, in order for adverse selection to arise there. The need to separate over different parts of bank decisions is seen elsewhere in the literature. For instance, in the literature on bank competition, the competition on the market for borrowers (banks' asset side) has to precede competition on the market for depositors (banks' liability side), otherwise equilibria may fail to exist (Stahl, 1988).

Banks enter the game with internal funds worth $e<1$, i.e. internal equity. We assume that these internal funds have been previously committed to the bank's project. Thus if the bank is hit by a negative solvency shock, that is, it becomes unsound, then it loses its equity value.

Since internal funds are less than 1, if banks wish to give their initial project the full funding it requires to generate return $R$, they need to obtain additional funds. We assume that they can only do this by turning to the market for wholesale debt funding. That is, we abstract from deposit-insured retail deposits as well as from the issuance of additional external equity. ${ }^{5}$ Over the past decades wholesale funding has become an increasingly prevalent form of bank funding, and its importance in banks' activities has been highlighted by the recent financial crisis. ${ }^{6}$ In our main model we focus on this type of financing because it reacts to bank riskiness, unlike largely insured retail deposits, and because it is this wholesale market that experienced a freeze during the recent crisis, rather than insured retail deposits on which relatively few runs were seen. In section $5 \mathrm{C}$ we extend to a mixed funding structure that includes both retail and wholesale depositors.

Like in Freixas, Parigi and Rochet (2004), the funding market is assumed to be perfectly competitive, infinitely elastic in supply and its participants are risk neutral. Though financiers do not observe the asset structure of a given bank, they do know the parameters of the model and can compute the probability that they are facing a sound or an unsound bank. They accordingly charge banks a fair risk premium. Without loss of generality, we

\footnotetext{
${ }^{5}$ Abstracting from the issuance of external equity is quite common in the literature (Thakor, 1996; Acharya, Mehran and Thakor, 2010). Essentially, this is a reduced form for asymmetric information arguments that make external equity a relatively expensive form of finance (Myers and Majluf, 1984).

${ }^{6}$ See Brunnermeier (2009), Allen, Carletti and Gale (2009), Diamond and Rajan (2009) and LópezEspinosa and others (2012)
} 
set the risk-free rate to zero, so that the gross market borrowing rate for banks, $r$, is purely a reflection of banks' default risk.

The assumption that bank financiers are uninformed on bank asset quality mirrors the lack of knowledge on bank exposures exhibited by such creditors when the global financial crisis unfolded, a key factor in the ensuing funding market freeze (Heider, Hoerova and Holthausen, 2009). Nonetheless, while a useful baseline assumption, a complete lack of creditor information on individual bank exposures is rather extreme and we therefore relax this assumption in an extension, section $5 \mathrm{~A}$.

\section{Bank maximization}

Let us define $d=1-e$ as the amount a sound bank needs to borrow so that, if invested in its project, it yields return $R$. We assume the following parameter restriction:

$$
x>\frac{R}{d}
$$

This means that the return on a successful gamble has to be sufficiently large. When this is the case, we can show that unsound banks will always choose to gamble, and that by backward induction a bank's stage 1 optimization problem is given by:

Lemma 1 At stage 1 a bank maximizes to $q_{i}$

$$
E\left[\Pi_{i}\right]=\left\{\begin{array}{l}
q_{i}(R-r d)+\left(1-q_{i}\right) \rho d(x-r)-c q_{i}^{2} \text { if } R-r d \geq e+\max \{\rho d(x-r), 0\} \\
q_{i}(e)-c q_{i}^{2} \text { otherwise }
\end{array}\right.
$$

Proof. In the appendix.

Here the condition

$$
R-r d \geq e+\max \{\rho d(x-r), 0\}
$$

is what we term the no-breakdown condition, because if it is not satisfied then the funding market freezes. That is, as shown in the proof of Lemma 1, when this condition is not satisfied then financiers realize they face only gambling banks and provide no funds. In this case banks can do no better than to optimize over $q_{i}(e)-c q_{i}^{2}$ which is merely about monitoring the entrepreneur so as to prevent him from running off with the funds already given to him. Instead, if condition (3) holds then the bank earns $R-r d$ if it has a sound project, while it receives an expected return from gambling of $\rho d(x-r)$ if it has an unsound project. Note that in condition (3) we have made the tie-breaking assumption that if banks are indifferent between alternatives then they choose to invest in their project (hence the weak inequality). 


\section{Breakdown threshold}

Definition 2 Funding market breakdown occurs when there exists no interest rate at which financiers are willing to lend to banks.

We can provide a full analytical solution for the no-breakdown condition in (3) if we replace for the endogenous interest rate, $r$. But the existence of that interest rate depends on whether

or not breakdown occurs. We solve this with the following procedure:

Step 1 Derive the interest rate assuming that the no-breakdown condition holds.

Step 2 Solve for the no-breakdown condition and the equilibrium given that interest rate.

Step 3 Verify if the no-breakdown condition indeed holds.

Assuming that the no-breakdown condition holds, the fair market rate for bank funding is given by

$$
r=\frac{1}{q^{*}+\left(1-q^{*}\right) \rho}
$$

where $q^{*}$ is the equilibrium monitoring effort of banks. In equilibrium, with probability $q^{*}$ financiers get their money back for sure, while with probability $\left(1-q^{*}\right)$ they face a gambling bank and get their money back only with probability $\rho$.

Lemma 3 Given $r$ as in (4) the no-breakdown condition (3) can be written to:

$$
q^{*}>\widehat{q}=\max \left\{\frac{1-\rho x}{x(1-\rho)}, \frac{d}{R-1+d(1-\rho x)}-\frac{\rho}{1-\rho}\right\} \in(0,1)
$$

Proof. In the appendix.

In the form of (5) the no-breakdown condition says that the equilibrium monitoring effort of banks, $q^{*}$, must be above a certain threshold, $\widehat{q}$. If it falls below that threshold then adverse selection problems become too severe and the funding market freezes. The determinants of that threshold are quite intuitive. For instance, the threshold falls when asset returns $(R)$ increase or leverage $(d)$ decreases, because this raises the attractiveness of the sound project as compared to a gamble. However, the gambling parameters $x$ and $\rho$ have ambiguous effects on the breakdown threshold. For instance, a higher $\rho$ raises banks' charter values (ceteris paribus $r$ declines in equation 4), which reduces gambling incentives, but also increases the expected return on gambling relative to sound investments (the right-hand side of equation 3 ), which works in the opposite direction. 


\section{E. Reaction function}

If the no-breakdown condition holds, then by Lemma 1 a bank solves

$$
\max _{q_{i}}\left\{q_{i}(R-r d)+\left(1-q_{i}\right) \rho d(x-r)-c q_{i}^{2}\right\}
$$

The solution to this, $q_{i}^{*}$, is

$$
q_{i}^{*}=\frac{R-d[r(1-\rho)+\rho x]}{2 c}
$$

and replacing for $r$ from equation (4) this becomes

$$
q_{i}^{*}=\frac{1}{2 c}\left[R-d\left(\frac{1-\rho}{q^{*}(1-\rho)+\rho}+\rho x\right)\right]
$$

Equation (8) is a bank's reaction function, reflecting how at given behavior of other banks, $q^{*}$, an individual bank best responds. When asset returns $(R)$ increase, then there is a higher return on monitoring, since a successful project is worth more. The opposite is true for higher leverage $(d)$, while for a larger $c$ monitoring is more expensive and so banks do less of it. Only the probability of success of the gamble $(\rho)$ enters ambiguously, with the same type of countervailing effects discussed before.

Lemma 4 A bank's optimal monitoring effort is increasing and concave in other banks' monitoring effort: $\frac{\partial q_{i}^{*}}{\partial q^{*}}>0$ and $\frac{\partial^{2} q_{i}^{*}}{\partial\left(q^{*}\right)^{2}}<0$.

Proof.

$$
\frac{\partial q_{i}^{*}}{\partial q^{*}}=\frac{1}{2 c} \frac{(1-\rho)^{2} d}{\left[q^{*}(1-\rho)+\rho\right]^{2}}>0
$$

and

$$
\frac{\partial^{2} q_{i}^{*}}{\partial\left(q^{*}\right)^{2}}=-\frac{1}{c} \frac{(1-\rho)^{3} d}{\left[q^{*}(1-\rho)+\rho\right]^{3}}<0
$$

Intuitively, this means that when other banks monitor more a given bank has greater incentive to monitor: there is a cross-sectional complementarity in monitoring effort. The reason is that when $q^{*}$ increases, the funding rate $(r)$ falls, which raises a given bank's charter value. That is, the profits from a fully funded sound project $(R-r d)$ increase, strengthening banks' incentives to make sure that their projects are sound by monitoring the entrepreneurs more intensely.

Moreover, the marginal effect on the funding rate is strongest when $q^{*}$ is low. For higher levels of monitoring the impact on $r$ flattens out. This is what explains the concavity of $q_{i}^{*}$ in $q^{*}$. 


\section{Equilibria}

A one-shot, non-cooperative Nash equilibrium is defined by the absence of an incentive to deviate by any of the players. This can only occur at a point where, when other banks invest $q^{*}$ in monitoring, a bank's individually optimal monitoring is the same (interior equilibrium, $\left.q_{i}^{*}=q^{*}\right)$ or cannot be changed farther in the desired direction (corner solution).

Let us additionally define the concepts of stable and unstable interior equilibria:

Definition 5 An interior equilibrium $\left(q_{i}^{*}=q^{*} \in(0,1)\right)$ is said to be stable when at that equilibrium, $\frac{\partial q_{i}^{*}}{\partial q^{*}}<1$, and is unstable otherwise.

The concept of stability refers to the direction of play in the vicinity of an equilibrium. Corner equilibria are necessarily stable: they occur by the very fact that at a corner $\left(q^{*}=0\right.$ or $q^{*}=1$ ) banks want to further decrease / increase their monitoring but cannot. Instead, an interior equilibrium can be unstable, when a marginal perturbation in other banks' play $\left(+\varepsilon\right.$ or $-\varepsilon$ compared to the $q^{*}$ for which $q_{i}^{*}=q^{*}$ ) will make an individual bank take its monitoring level farther away from that equilibrium. This will become clear in the game's graphical representation below (figures 3 and 4).

\section{A. The constellations}

Proposition 6 There are three possible constellations of Nash equilibria:

\begin{tabular}{|l|}
\hline I. One equilibrium: low-end corner \\
\hline II. Three equilibria: one interior (unstable), both corners \\
\hline III. Three equilibria: two interior (one stable, one unstable), one low-end corner \\
\hline
\end{tabular}

Proof. In the appendix.

We first describe these constellations graphically, and after that derive the exact parametric conditions under which each constellation occurs.

In the proof it is shown that at $q^{*}=0$ it always holds that $q_{i}^{*}<0$. Graphically this means that, when plotting a bank's optimal monitoring $\left(q_{i}^{*}\right)$ against $q^{*}$, a bank's reaction function always starts below the 45 degree line. Moreover, by Lemma 3 we know that the reaction function is increasing and concave. One possibility is that the reaction function is as in figure 2 : 


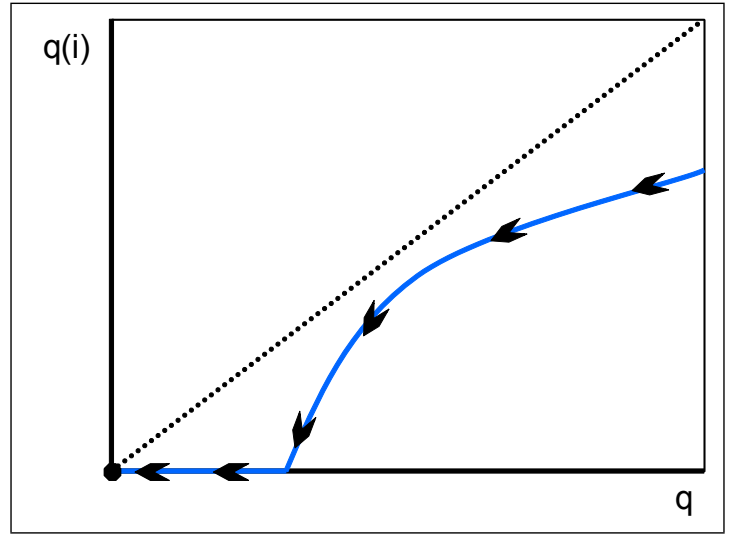

Figure 2: Low-end corner only

Here the dotted line is the 45 degree line, while the solid line is an individual bank's reaction function. An interior equilibrium can only occur at a point where the reaction function crosses the 45 degree line. In this figure that does not happen. That is, within the entire domain of $q^{*} \in[0,1]$ there is no crossing point. The black arrows on the reaction function give the direction in which the game evolves. For any given play of other banks, an individual bank will set a lower monitoring effort than they do. The fact that the reaction function is below the 45 degree line is the visual representation of this: it means that at any given $q^{*}$ a bank's optimal monitoring $q_{i}^{*}$ is smaller than $q^{*}$. Since all banks are identical, all lower their monitoring effort. The only Nash equilibrium is the low-end corner, where monitoring is zero. This is Case I in Proposition 1.

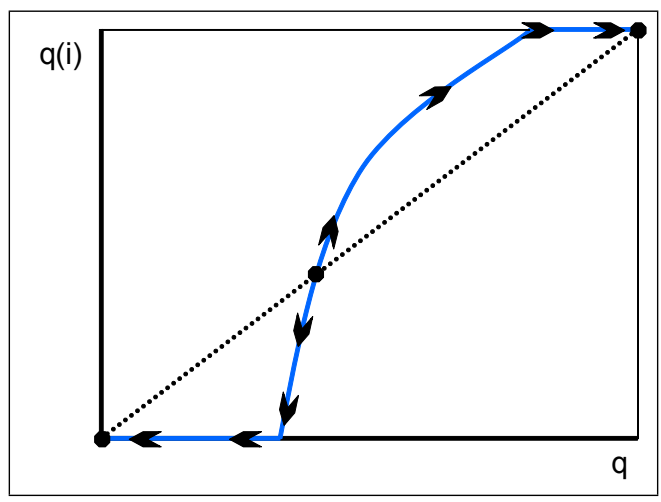

Figure 3: One interior equilibrium, two corners

If the bank's reaction function does cross the 45 degree line, then it can do so once, as in figure 3 , or twice, as in figure 4 . In figure 3 there is a single interior equilibrium. This equilibrium is unstable, which visually means that the arrows point outwards. Any perturbation in banks' expectations about each other, and play moves away from this equilibrium. The reason is that to the right of the equilibrium the reaction function is above the 45 degree line, and this implies that an individual bank optimally sets higher monitoring effort than other banks, for any given effort of other banks. Hence the only outcome is the high-end corner with 
maximum monitoring $\left(q^{*}=1\right)$. And to the left of the interior equilibrium, the reaction function is below the 45 degree line, so that like in figure 2, the low-end corner ensues as equilibrium. Hence, figure 3 depicts Case II in Proposition 1.

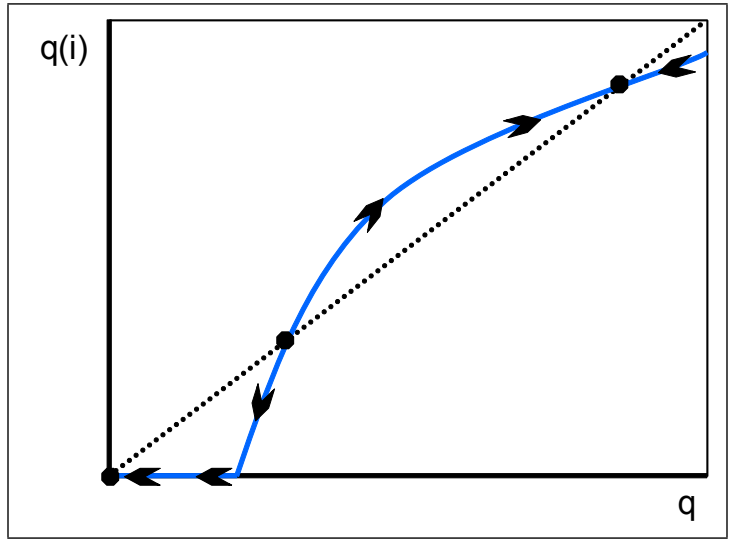

Figure 4: Two interior equilibria

Instead, if the reaction function crosses the 45 degree line twice, then there is also one stable interior equilibrium. This is shown in figure 4, where the arrows outside of the rightmost equilibrium point back towards that equilibrium. Both an unstable interior equilibrium and the low-end corner also remain feasible, however. Figure 4 therefore depicts Case III in Proposition 1.

\section{B. Parameter conditions}

Proposition 7 The conditions for the constellations to occur are:

\begin{tabular}{|c|c|}
\hline \multicolumn{2}{|c|}{ Case II if and only if: $R>2 c+d(1+\rho(x-1))$} \\
\hline Case III if and only if all of: & $\begin{array}{l}R \leq 2 c+d(1+\rho(x-1)) \\
R>2 \sqrt{2 c d}+\rho x d-\frac{2 c \rho}{1-\rho} \\
\left(\sqrt{\frac{d}{2 c}}-\frac{\rho}{1-\rho}\right) \in[0,1]\end{array}$ \\
\hline Case I for a & \\
\hline
\end{tabular}

Proof. In the appendix.

The first thing that stands out from Proposition 2 is that Case III requires rather many conditions. Indeed, in our numerical examples in the next section, we find that it is difficult to generate Case III, especially for realistic ranges of parameter values. When Case III does not come about, the model boils down to Case II versus Case I. This is as depicted in figure 1 in the introduction, the comparative statics of which we can now observe formally.

Consider that the values of $c, d, \rho$ and $x$ are given and we vary the return on bank assets, $R$. Let us take three values, a high $R_{H}$, a medium $R_{M}$ and a low $R_{L}$. And let us choose 
them such that $R_{H}$ and $R_{M}$ satisfy the condition for Case II, while $R_{L}$ does not:

$$
R_{H}>R_{M}>2 c+d(1+\rho(x-1)) \geq R_{L}
$$

Figure 5 then displays the comparative statics.

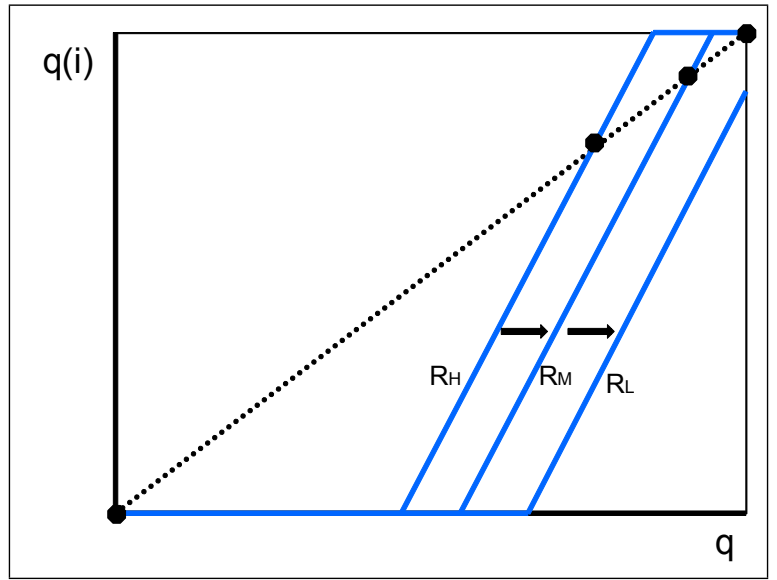

Figure 5: The effects of falling returns

When $R$ declines then, for any given $q^{*}$, an individual bank's optimal monitoring effort, $q_{i}^{*}$, is lower. This can be seen from equation (8) and implies a rightward shift in the reaction function. However, quite surprisingly, the interior equilibrium for $R=R_{M}$ involves larger monitoring effort than for $R=R_{H}$. Even though for each given value of other banks' monitoring, $q^{*}$, a given bank sets lower monitoring effort when $R=R_{M}$, the interior equilibrium occurs at a higher point. Thus, if we follow the movement of the interior equilibrium: when bank asset returns fall we first observe a decline in bank default rates $\left(1-q_{i}^{*}\right)$. But if returns fall even farther, we reach the line $R_{L}$ where no interior equilibrium exists at all and the unique equilibrium is the low-end corner. In that sense, the model cautions that the observation of low or falling default rates need not be a sign of increased financial stability, but may to the contrary, be indicative of the silence before the storm.

Looking at the high-end corner equilibrium, the movement between the three lines tells a story of non-linear response. In a decline from $R_{H}$ and $R_{M}$ nothing happens, and default rates remain zero. But the next decline in $R$, from $R_{M}$ to $R_{L}$, causes a jump from one corner to the other.

\section{Numerical examples}

We further highlight the model's comparative statics using a few quantitative examples. These examples are not intended to be calibrations. We do discuss the realism of the assumed parameter values, however, to give some feeling for the numbers. 


\section{A. An example of Case II}

In our first example banks' debt ratio is $92.5 \%(d=0.925)$ (i.e. banks have $7.5 \%$ own capital) and the recovery rate on loans to unsound banks is $50 \%(\rho x=0.5)$. Our exercise consists of reducing the return on sound bank assets from $10 \%$ to $8 \%(R=1.10$ to $R=1.08)$, and we use the free parameter $c$ (monitoring costs, on which there is little empirical "feeling") to match the initial (interior equilibrium) survival probability of banks at $99 \%\left(q^{*}=0.99\right)$. This is near the value banks were required to achieve in their Value at Risk models by regulation under Basel II (99.5\%), and a capitalization of 7.5\% is also in line with Basel minima. However, the assumed return on assets and the recovery rate are somewhat higher than what would be expected empirically. For instance, realistic recovery rates for loans to distressed banks are in the order of 35\% (Altman and Kishmore, 1996).

We pin down $x$ at its lower bound from condition (1), and then impute $\rho$ from the value given for the recovery rate. This gives $c=0.048, x=1.19$, and $\rho=\frac{0.5}{x}=0.42$.

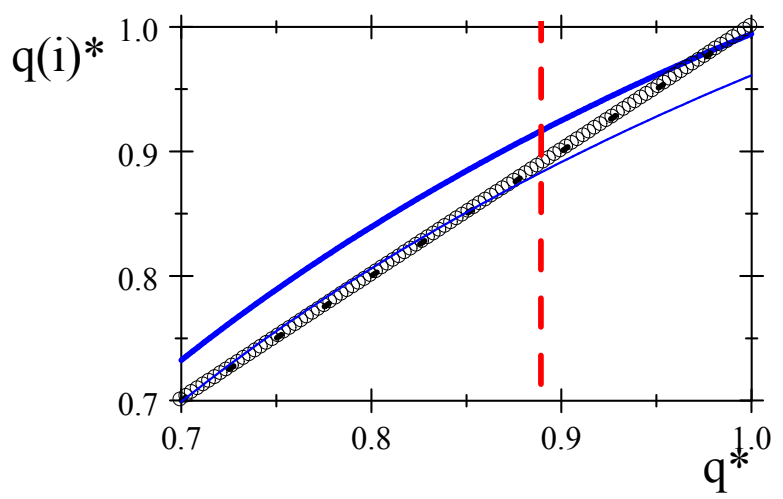

Figure 6: From Case II to Case I

The outcome is shown in figure 6 . Here the dashed vertical line is the breakdown threshold, the thick solid line is the reaction function when the return on sound assets $(R)$ is $10 \%$, while the thin solid line is that reaction function when the return is $8 \%$. The outcome is like the comparative statics in figure 5. Initially the financial sector could be at an interior equilibrium with very low default rates or a high-end corner with zero default. But a small drop in returns leads to certain market gridlock. In fact, the lower is default risk in the initial interior equilibrium (i.e. the closer the crossing point of the reaction function with the 45 degree line is to the top-right corner), the greater the systemic sensitivity of the funding market, because it takes a smaller shock to instigate breakdown.

\section{B. An example of Case III}

Figure 7 provides a quantitative example of a shift to breakdown starting from a stable, interior equilibrium, like the rightmost equilibrium in figure 4 . We start from parameterization 
$R=1.1, d=0.45, x=\frac{R}{d}, \rho=\frac{0.2}{x}$ and $c=0.3$. This gives the thick solid line in figure 7 with a stable, interior equilibrium near maximum monitoring effort, and located quite far above the breakdown threshold. This parameterization is not very realistic, as can be seen from the debt ratio of $45 \%$. We did not manage to generate Case III for more plausible parameter values, however. Quantitatively it is easier to generate graphs like figure 3 than like figure 4 , because the latter requires a large degree of concavity that does not easily come about. For example, in figure 6 , it is not visible to the eye that the reaction function is concave.

To highlight that shocks need not only be to asset returns, we here consider an increase in leverage as a shock. In particular, an increase of the debt ratio from $45 \%$ to $50 \%$ (the thin solid line) eradicates the interior equilibrium and leads to funding market breakdown. This shows once more how intra-equilibrium default risk may be small while sensitivity across equilibria is large.

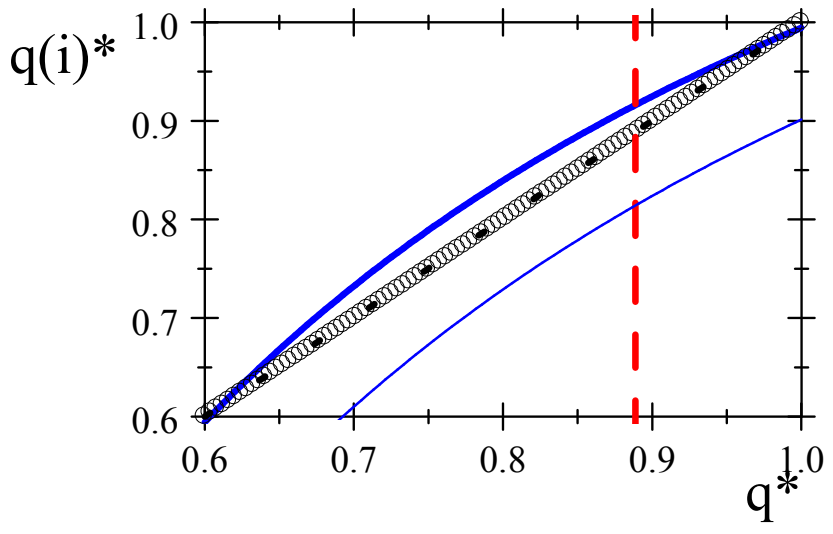

Figure 7: From Case III to Case I

\section{Endogenous breakdown threshold}

In the above examples we did not show how the breakdown threshold, which is endogenous, shifts in response to shocks. Depicting this was of little relevance, since the shock leads to breakdown regardless of the final location of the threshold. However, there are cases in which no shift to another equilibrium occurs, but nonetheless a shock leads to breakdown, because it pushes the threshold beyond the location of that equilibrium. Take the example in figure 7 , and consider the case of a declining return on assets. If the breakdown threshold were constant, the funding market could survive a reduction of asset returns down to $R=1.085$. But since the threshold itself shifts rightward, breakdown already occurs below $R=1.09$, which is shown in figure 8 , where the thin dashed line is the threshold after the shock.

This is not a point about the difference between risk within and across equilibria, but rather a cautioning about the "perceived" distance to breakdown within an equilibrium. If a regulator were to take the amount of stress that the market can handle as given, and focus only on how shocks affect bank profitability, he would overestimate the resilience of the financial sector. 


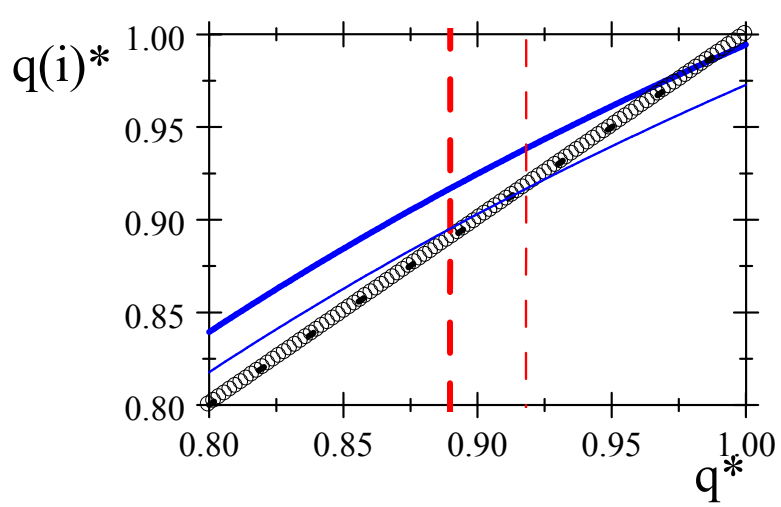

Figure 8: Breakdown threshold shift

\section{Extensions}

\section{A. Informed creditors}

The central role of creditor information in the functioning of the wholesale funding market in general, and during the recent crisis specifically, has been highlighted by recent research. ${ }^{7}$ Our main model assumes that creditors are entirely uninformed about the soundness of individual banks. In this extension we relax that assumption.

Starting from the timing of the basic game in table 2, we add a stage on creditor information. This stage occurs after the realization of project soundness and the banks' decision about gambling. This is shown in table 3 .

\begin{tabular}{|l|}
\hline \multicolumn{1}{|c|}{ Stage } \\
\hline 1. Banks set monitoring effort \\
\hline 2. Project soundness realizes \\
\hline 3. Banks decide on gambles \\
\hline 4. Creditor information realizes \\
\hline 5. Bank funding \\
\hline 6. Projects and gambles pay out \\
\hline
\end{tabular}

Table 3: Timing of the game with creditor information

In particular, we assume that bank portfolios are revealed to the wholesale funding market with probability $\varphi \in(0,1)$. Using this probability will allow us to perform a comparative static exercise to the extent of creditor information.

\footnotetext{
${ }^{7}$ See Cocco and others (2009), Eisenschmidt and Tapking (2009), Dinger and Von Hagen (2009), Fecht, Nyborg and Rocholl (2011), Affinito (2012), De Socio (2013) and Afonso, Kovner and Schoar (2013).
} 
There are now four possible states that a bank can be in when turning to the funding market at stage 5: sound \& creditors know; unsound \& creditors know; sound \& creditors do not know; unsound \& creditors do not know. If creditors do not know the portfolio of the bank, then $r$ from equation (4) is the same as in the main model. If instead creditors do become informed at stage 4, then they charge a gross interest rate of 1 to sound banks and are unwilling to lend to unsound banks. We now let the variable $r$ stand for the interest rate that is charged by creditors in the event that they are uninformed, and write the bank's maximization problem as:

$$
E\left[\Pi_{i}\right]=\left\{\begin{array}{c}
(1-\varphi) q_{i}(R-r d)+(1-\varphi)\left(1-q_{i}\right) \rho d(x-r)+\varphi q_{i}(R-d)-c q_{i}^{2} \\
\text { if } R-r d \geq e+\max \{\rho d(x-r), 0\} \\
q_{i}(e)-c q_{i}^{2} \text { otherwise }
\end{array}\right.
$$

where the terms that occur when bank quality remains private knowledge are multiplied by $(1-\varphi)$, whereas if bank quality is revealed then only sound banks receive funding, which is captured by the term $\varphi q_{i}(R-d)$.

The no-breakdown condition from Lemma 2 is unchanged, but now only applies when creditors are uninformed. If creditors are informed then breakdown cannot occur, since there is no longer any information asymmetry.

The adjusted bank optimization problem gives us the following reaction functions:

$$
\begin{aligned}
q_{i}^{*} & =\frac{R-r d+\varphi d(r-1)-(1-\varphi) \rho d(x-r)}{2 c} \\
r & =\frac{1}{q^{*}+\left(1-q^{*}\right) \rho}
\end{aligned}
$$

From this we can see that $q_{i}^{*}$ is monotonically increasing in $\varphi$. Hence, a greater probability of information revelation at stage 4 makes banks exert more monitoring effort at stage 1. The intuition is that a bank sees more benefits to monitoring when it is more likely that the bank's asset quality will affect its funding cost. In other words, lessening information asymmetries limits the "free-rider" incentives that make a bank cut back on monitoring, since now the bank can no longer fully externalize the premium for its additional risk to the rest of the funding market.

\section{B. Idiosyncratic bank soundness}

An important element in discussions about macroprudential regulation is the correlation in bank exposures. In fact, most of the methods that have been developed to gauge the extent of systemic risk, use the commonality of bank exposures as the basis for their measure. ${ }^{8}$ We can extend our model to incorporate banks that are not identical. In this extension we

\footnotetext{
${ }^{8}$ See Adrian and Brunnermeier (2011), Acharya and others (2012), Bisias and others (2012) and Löffler and Raupach (2013).
} 
introduce an idiosyncratic element in the probability that a project is sound. This allows us to vary the correlation of bank portfolios.

We rewrite the probability of project soundness to

$$
p_{i}=q_{i}+\nu_{i}
$$

where the probability of soundness, $p_{i}$, depends on both the monitoring effort, $q_{i}$, and on the idiosyncratic component, $\nu_{i}$. The idiosyncratic component, $\nu_{i}$, is a random draw from a uniform distribution with support between 0 and $a: \nu_{i} \sim U(0, a)$ with $a \in(0,1)$. To ensure that the probability of bank soundness, $p_{i}$, is between 0 and 1 , we rescale the bank's choice variable to $q_{i} \in[0,(1-a)]$.

The idiosyncratic component is drawn at the outset of the game and is private information to the bank. Bank creditors only know the overall distribution of $\nu_{i}$, and thus the information asymmetry of the main model is retained in the extension.

The expected profit of the bank becomes

$$
E\left[\Pi_{i}\right]=\left\{\begin{array}{l}
p_{i}(R-r d)+\left(1-p_{i}\right) \rho d(x-r)-\frac{c}{1-a} q_{i}^{2} \text { if } R-r d \geq e+\max \{\rho d(x-r), 0\} \\
p_{i}(e)-\frac{c}{1-a} q_{i}^{2} \text { otherwise }
\end{array}\right.
$$

where the cost of monitoring, $\frac{c}{1-a}$, is adjusted according to the rescaling of bank monitoring effort, $q_{i} \in[0,(1-a)]$.

The interest rate now becomes

$$
r=\frac{1}{\left(q^{*}+E\left[\nu_{i}\right]\right)+\left(1-\left(q^{*}+E\left[\nu_{i}\right]\right)\right) \rho}=\frac{1}{q^{*}+a / 2+\left(1-q^{*}-a / 2\right) \rho}
$$

Following the computations in the proof of Lemma 2, moreover:

$$
q^{*}>\widehat{q}=\max \left\{\frac{1-\rho x}{x(1-\rho)}, \frac{d}{R-1+d(1-\rho x)}-\frac{\rho}{1-\rho}\right\}-\frac{a}{2}
$$

and solving for the bank's optimization problem gives

$$
q_{i}^{*}=\frac{1-a}{2 c}\left[R-d\left(\frac{1-\rho}{q^{*}+a / 2+\left(1-q^{*}-a / 2\right) \rho}+\rho x\right)\right]
$$

The correlation between bank exposures depends on the parameter $a$. For $a \rightarrow 0$ we are back at the main model, where banks are identical. Instead, for $a \rightarrow 1$ project soundness is completely idiosyncratic. Thus, we analyze the effects of increasing $a$, i.e., reducing the correlation between bank exposures. Intuitively, we would expect a larger $a$ to reduce the occurrence of systemic crises, because when banks differ more from each other, they are less likely to simultaneously fail. The model paints a more nuanced picture, however. The breakdown threshold, $\widehat{q}$, indeed declines in $a$. However, a larger $a$ has an ambiguous effect on a bank's monitoring incentives: $q_{i}^{*}$ may increase or decrease, depending on other parameters. 
On the one hand, funding market pressures decline when bank portfolios differ more from each other. The reason is that banks play less on the adverse selection problem. Banks cannot externalize part of the premia for their risk taking to the funding market when their default risk is idiosyncratic. Hence, the funding rate, $r$, declines. A lower funding cost means that a bank's charter value increases and this pushes up bank monitoring, $q_{i}^{*}$. On the other hand, a larger random, idiosyncratic component in a bank's portfolio weakens the link between how much a bank invests in monitoring and the probability that it will default. This effect reduces optimal monitoring, $q_{i}^{*}$. All in all this extension finds an ambiguous relationship between the correlation of bank exposures and the risk of market breakdown.

\section{Retail depositors}

Since the global financial crisis the role of banks' funding structures in the formation of systemic risk has taken center stage in the policy debate. ${ }^{9}$ Indeed, the Basel III accord includes specific measures that are geared towards discouraging banks' reliance on shortterm wholesale debt. The "net stable funding ratio" sets down regulatory lower bounds for stable funding, which excludes most market-based funding with maturities less than one year (BIS, 2010).

We can extend our model to analyze the relation between bank funding modes and the risk of a system-wide freeze. In particular, we include retail deposits in the model, which enables a comparison between the effects of wholesale and retail funding within our context. That is, we consider a mixed funding structure. Of the funding of 1 that the bank needs in order to finance its project, $e$ comes from equity, $w$ comes from wholesale funding and $d$ comes from retail deposits. Retail deposits are assumed to be fully insured and pay the (zero) risk-free rate.

The bank's maximization problem becomes

$$
E\left[\Pi_{i}\right]=\left\{\begin{array}{c}
q_{i}(R-r w-d)+\left(1-q_{i}\right) \rho((w+d) x-r w-d)-c q_{i}^{2} \\
\quad \text { if } R-r w-d \geq e+\max \{\rho((w+d) x-r w-d), 0\} \\
q_{i}(e)-c q_{i}^{2}+\rho d(x-1) \text { otherwise }
\end{array}\right.
$$

The funding rate, $r$, is unchanged compared to the main model. However, following the same derivation as in the proof of Lemma 2, the solution for the no-breakdown condition, becomes

$$
q^{*}>\widehat{q}=\max \left\{\frac{w}{(R-d-e)-\rho[(w+d) x+d]}, \frac{w}{(1-\rho)[(w+d) x-d]}\right\}-\frac{\rho}{1-\rho}
$$

Moreover, bank optimization gives

$$
q_{i}^{*}=\frac{1}{2 c}\left[R-(1-\rho)\left[d+\frac{w}{q^{*}(1-\rho)+\rho}\right]-\rho x(w+d)\right]
$$

\footnotetext{
${ }^{9}$ See, for instance, Brunnermeier and others (2009), Claessens and others (2010), Perotti and Suarez (2011), Galati and Moessner (2012) and Arnold and others (2012).
} 
where $\left[q^{*}(1-\rho)+\rho\right] \leq 1$. This means that replacing wholesale with retail deposits (that is, raising $d$ and equivalently lowering $w$ ) increases the bank's optimal monitoring effort, $q_{i}^{*}$. Moreover, $\widehat{q}$, declines in this case. Thus, the model indicates that retail funding makes a freeze on banks' funding market less likely. This result is in line with the efforts of macroprudential policy makers to reduce the dependence of banks on wholesale funding. In the context of our model, retail funding makes banks internalize more of the benefits of having a sound project. The externality to the funding market - the fact that one bank's increased effort lowers all banks' funding costs - does not come about with retail funding.

\section{Conclusions}

Banks' portfolio decisions and their funding strategies can interact in intricate ways. This paper combines two well-known aspects of the asset and liability sides of bank balance sheets and analyzes their interaction. These aspects are moral hazard in banks' monitoring and adverse selection on their funding market. The interaction between these aspects gives rise to non-linear effects. Parameter changes, such as a decline in asset returns, may have little effect sometimes and yet suddenly cross a threshold that spirals the financial system into crisis. Essentially, we identify differences between movements within an equilibrium and across equilibria. Although the multiplicity of equilibria has been a common feature of the banking literature, the ability to relate equilibrium shifts to parameters is rare. Our model also allows us to distinguish between stable and unstable equilibria, which is ordinary in non-linear modeling, but is new to banking theory.

In three extensions of the model, we find that, firstly, better information among bank creditors alleviates the risk of a systemic freeze. Secondly, reducing the extent of correlation among bank portfolios does not necessarily make banks' funding market more robust. And, thirdly, increasing the share of retail deposits in bank funding reduces the systemic vulnerability of the wholesale market.

Our results relate to ongoing debates about macroprudential regulation, both at the conceptual level and in terms of concrete policies. At the conceptual level the results relate to "regulatory awareness", "regulatory preferences" and "regulatory transparency". Our model indicates that regulators should be at the highest state of awareness when the financial system seems particularly stable. This also hints at the difficulty of designing effective early warning systems, as the data may look deceptively benign prior to a crisis. Our model suggests, moreover, that there is a role for a debate on regulatory preferences. If banks indeed interact in the manner depicted by figure 1 in the introduction, then the regulator faces a trade-off between microprudential and macroprudential concerns. Lowering individual bank default risk can bring banks closer to the precipice of a systemic freeze.

Furthermore, our model suggests that if regulators possess more information than wholesale financiers, then regulators' transparency about this affects systemic risk. In contrast to monetary authorities who have placed increasing focus on transparent communication (Blinder and others, 2008), bank regulators have traditionally tended to be weary of public commu- 
nication about the health of the banks that they supervise. However, creditors' knowledge that the system as a whole is troubled, but not which banks are the rotten apples, gives rise to the sudden equilibrium shifts we have analyzed in this paper.

In terms of concrete macroprudential policies this paper feeds into the discussions on the modes of bank funding and on limiting the correlation of bank exposures. While our model lends support to policies that limit banks' reliance on wholesale funding, it provides a cautioning note on the benefits of limiting banks' correlation. The implication is that if macroprudential regulators design a systemic risk taxation they should probably not solely focus on incentivizing banks to reduce the degree of common exposures. 


\section{Appendix: Proofs}

\section{Proof of Lemma 1}

At stage 4 of the game depicted in table 2 banks always demand an amount of $d$ on the funding market. This is true both for banks that want to invest the funds in sound projects and for those who want to invest in gambles. By the payoff given in table 1, for a sound bank investing in its project yields zero net return unless a total funding of 1 is provided to it. Given that banks that invest in sound projects always choose to borrow $d$, so do gambling banks. Borrowing any less would immediately reveal to financiers that the bank is using the money for a gamble. As argued in the text, by $(\sup \rho r)=\rho x<1$, there exists no interest rate at which a financier is willing to lend to a bank that is known to gamble.

As banks always demand funding $d$, then under conditions discussed below, at stage 1 a bank solves

$$
\max _{q_{i}}\left\{q_{i}(R-r d)+\left(1-q_{i}\right) \rho d(x-r)-c q_{i}^{2}\right\}
$$

where ex-ante there is a probability of $q_{i}$ that the bank has a sound project and obtains a gross return of $R$ on invested funds $e+d=1$, while it repays $r$ on borrowed funds $d$, so profits are $R-r d$. And with probability $1-q_{i}$ the bank's project is unsound, which implies that it becomes a gambler, borrowing funds $d$ on which it receives gross return $x$ and repays $r$ if the gamble is successful, so expected profits are $\rho d(x-r)$.

For this to be the case there are three participation constraints and two incentive compatibility constraints that need to be satisfied. Namely:

1. Sound banks prefer their initial project to a gamble (incentive compatibility of sound banks).

2. And the profit of investing in the initial project is positive (participation constraint of sound banks).

3. Unsound-project banks prefer the gamble to their initial project (incentive compatibility of unsound banks).

4. And the expected profit of the gamble is positive (participation constraint of unsound banks).

5. There exists an interest rate, $r$, at which financiers are willing to fund banks (participation constraint of bank financiers).

The first two of these are summarized by the condition given in equation (3), namely

$$
R-r d \geq e+\max \{\rho d(x-r), 0\}
$$


since $R-r d$ is the return of borrowing $d$ and investing in the sound project, $e$ is the return if a sound bank does not borrow (invests in the risk-free technology), and $e+\rho d(x-r)$ is the expected return if a sound bank borrows and invests the funds in a gamble.

The incentive compatibility constraint of the unsound banks to gamble (point 3) is automatically satisfied once their participation constraint (point 4) is satisfied. That is, when $x>r$ then gambles are profitable in expectation, which necessarily means that they also yield more than an unsound project whose gross return is 0 . But since

$$
\begin{aligned}
& R-r d \geq e+\max \{\rho d(x-r), 0\} \Rightarrow \\
& R-r d \geq e \Rightarrow R-r d \geq 0 \Leftrightarrow \frac{R}{d} \geq r
\end{aligned}
$$

then by the condition in (1) we have

$$
x>\frac{R}{d} \geq r
$$

and so the condition in (3) is sufficient to ensure $x>r$. This, by the arguments given in the text, is also sufficient to satisfy the bank financiers' participation constraint (point 5).

If the condition in (3) is not satisfied then it means that either $R-r d<e$ or $R-r d<$ $e+\rho d(x-r)$ or both. Therefore, either a sound bank chooses to gamble or it chooses not to borrow. In both cases, financiers then know that any bank that approaches them for funding (whether sound or unsound) wants to gamble. As previously discussed, when financiers know for certain that their funds are used to gamble then there exists no interest rate at which they are willing to lend, an implication of the fact that the gamble is value destroying. Thus, the funding market is closed, and all that banks can do is optimize with their internal funds, $e$ :

$$
\max _{q_{i}}\left\{q_{i}(e)-c q_{i}^{2}\right\}
$$

\section{Proof of Lemma 2}

We first write the no-breakdown condition to

$$
\begin{aligned}
R-r d & \geq e+\max \{\rho d(x-r), 0\}=\left\{\begin{array}{r}
R-r d \geq e+\rho d(x-r) \text { if } x>r \\
R-r d \geq e \text { otherwise }
\end{array}\right. \\
& =\left\{\begin{array}{c}
r \leq \frac{R-(1-d)}{d(1-\rho)}-\frac{\rho}{(1-\rho)} x \text { if } r<x \\
r \leq \frac{R-(1-d)}{d} \text { otherwise }
\end{array}\right.
\end{aligned}
$$

and replacing for $r$ from (4) and rewriting

$$
=\left\{\begin{array}{c}
\frac{1}{q^{*}+\left(1-q^{*}\right) \rho} \leq \frac{R-1+d(1-\rho x)}{d(1-\rho)} \text { if } \frac{1}{q^{*}+\left(1-q^{*}\right) \rho}<x \\
\frac{1}{q^{*}+\left(1-q^{*}\right) \rho} \leq \frac{R-(1-d)}{d} \text { otherwise }
\end{array}\right.
$$


where all numerators and denominators in all inequalities are positive, because $R>1$, $\rho x \in(0,1)$ and $\rho \in(0,1)$. Hence we know that division and multiplication do not change the signs of the inequalities, and we can write the inequalities to $q^{*}$ :

$$
=\left\{\begin{array}{c}
q^{*} \geq \frac{d}{R-1+d(1-\rho x)}-\frac{\rho}{1-\rho} \text { if } q^{*}>\frac{1-\rho x}{x(1-\rho)} \\
q^{*} \geq \frac{d(1-\rho)-\rho(R-1)}{[R-(1-d)](1-\rho)} \text { otherwise }
\end{array}\right.
$$

We can show, moreover, that

$$
\frac{d(1-\rho)-\rho(R-1)}{[R-(1-d)](1-\rho)}>\frac{1-\rho x}{x(1-\rho)}
$$

since

$$
\begin{aligned}
& \Leftrightarrow d(1-\rho) x-\rho(R-1) x>[R-(1-d)][1-\rho x] \\
& \Leftrightarrow d x-\rho x d-\rho x R+\rho x>R-\rho x R-1+d+\rho x-\rho x d \\
& \Leftrightarrow d(x-1)>R-1
\end{aligned}
$$

for which, from the condition in (1) $x>\frac{R}{d}$, it is sufficient that

$$
d\left(\frac{R}{d}-1\right)>R-1
$$

And rewriting further we have

$$
\Leftrightarrow R-d>R-1
$$

which is true by $d<1$.

Thus,

$$
q^{*} \leq \frac{1-\rho x}{x(1-\rho)} \Rightarrow q^{*}<\frac{d(1-\rho)-\rho(R-1)}{[R-(1-d)](1-\rho)}
$$

and hence, whenever $q^{*}>\frac{1-\rho x}{x(1-\rho)}$ does not hold breakdown certainly follows.

This means that we can write the no-breakdown condition to

$$
q^{*}>\widehat{q}=\max \left\{\frac{1-\rho x}{x(1-\rho)}, \frac{d}{R-1+d(1-\rho x)}-\frac{\rho}{1-\rho}\right\}
$$

because if if $q^{*} \leq \frac{1-\rho x}{x(1-\rho)}$ then breakdown follows as argued above, while if $q^{*}>\frac{1-\rho x}{x(1-\rho)}$ then by equation (21) no breakdown occurs if and only if $q^{*} \geq \frac{d}{R-1+d(1-\rho x)}-\frac{\rho}{1-\rho}$.

Furthermore, by $\rho x \in(0,1)$ and $\rho \in(0,1)$ we have that $\frac{1-\rho x}{x(1-\rho)}>0$ and, therefore, $\widehat{q}>0$. But also, we can write

$$
\frac{1-\rho x}{x(1-\rho)}<1 \Leftrightarrow 1-\rho x<x(1-\rho) \Leftrightarrow 1<x
$$


which holds by equation (1). Moreover,

$$
\begin{aligned}
\frac{d}{R-1+d(1-\rho x)}-\frac{\rho}{1-\rho} & <1 \Leftarrow \\
\frac{d}{(R-1)+d(1-\rho x)} & <1 \Leftarrow R>1 \wedge \rho x<1
\end{aligned}
$$

so that taken together $\widehat{q} \in(0,1)$.

\section{Proof of Proposition 1}

Firstly, in equation (8) $q_{i}^{*}<0$ for $q^{*}=0$. To see this, replacing $q^{*}=0$ write equation (8) to

$$
q_{i}^{*}=\frac{1}{2 c}\left[R-d\left(\frac{1}{\rho}(1-\rho)+\rho x\right)\right]
$$

where by $\frac{1}{\rho}>x>\frac{R}{d}$ we have that

$$
d\left(\frac{1}{\rho}(1-\rho)+\rho x\right)>d\left(\frac{R}{d}(1-\rho)+\rho \frac{R}{d}\right)=R
$$

which implies $q_{i}^{*}<0$.

This in conjunction with Lemma $3\left(q_{i}^{*}\right.$ increasing and concave in $\left.q^{*}\right)$ implies $q_{i}^{*}$ can have either 0,1 or 2 crossing points with $q^{*}$ in the domain $q^{*} \in[0,1]: 0$ if $q_{i}^{*}<q^{*} \forall q^{*} \in[0,1], 1$ if $q_{i}^{*}>q^{*}$ for some $q^{*} \in[0,1]$ and $q_{i}^{*}>q^{*}$ at $q^{*}=1$, and 2 if $q_{i}^{*}>q^{*}$ for some $q^{*} \in[0,1]$ and $q_{i}^{*} \leq q^{*}$ at $q^{*}=1$.

When $q_{i}^{*}<q^{*} \forall q^{*} \in[0,1]$, this means that for any given monitoring effort of other banks, $q^{*}$, an individual bank wants to set a lower monitoring effort, $q_{i}^{*}<q^{*}$. Thus, when there are 0 crossing points the only equilibrium is the low-end corner: $q_{i}^{*}=q^{*}=0$. This is Case I.

When $q_{i}^{*}>q^{*}$ for some $q^{*} \in[0,1]$ and $q_{i}^{*}>q^{*}$ at $q^{*}=1$, there necessarily is one interior equilibrium, and, by $q_{i}^{*}>q^{*}$ at $q^{*}=1$, also the high-end corner is an equilibrium: $q_{i}^{*}=q^{*}=$ 0 . Moreover, since we have shown that $q_{i}^{*}<0$ for $q^{*}=0$, the low end-corner is always an equilibrium. This comprises Case II.

When $q_{i}^{*}>q^{*}$ for some $q^{*} \in[0,1]$ and $q_{i}^{*} \leq q^{*}$ at $q^{*}=1$, then the high-end corner is not an equilibrium (by $q_{i}^{*} \leq q^{*}$ at $q^{*}=1$ ). The low-end corner, as said, is always a feasible equilibrium. The two crossing points are interior equilibria, where by Lemma 3, it must be that at the first crossing point $\frac{\partial q_{i}^{*}}{\partial q^{*}}>1$ and at the second $\frac{\partial q_{i}^{*}}{\partial q^{*}}<1$. This is Case III.

\section{Proof of Proposition 2}

Consider first Case II. We start from the observation that Case II comes about if and only if, in equation (8), at $q^{*}=1$ we have $q_{i}^{*}>1$ (see the proof of Proposition 1 ). Implementing 
$q^{*}=1$ into equation (8) then gives us the following condition:

$$
\begin{aligned}
\frac{1}{2 c}[R-d(1-\rho+\rho x)] & >1 \Leftrightarrow \\
R & >2 c+d(1+\rho(x-1))
\end{aligned}
$$

Next, we consider Case III. Firstly, for it to occur it must be that

$$
R \leq 2 c+d(1+\rho(x-1))
$$

since by the above we would otherwise be in Case II. Secondly, we prove that it must be that at the value of $q^{*}$ for which $\frac{\partial q_{i}^{*}}{\partial q^{*}}=1$, we have $q_{i}^{*}>q^{*}$, and that value of $q^{*}$ must be $\in[0,1]$ :

- Suppose not (part 1): the value of $q^{*}$ for which $\frac{\partial q_{i}^{*}}{\partial q^{*}}=1$ is $\in[0,1]$, but $q_{i}^{*} \ngtr q^{*}$ at that value. By by $\frac{\partial q_{i}^{*}}{\partial q^{*}}>0$ and $\frac{\partial^{2} q_{i}^{*}}{\partial\left(q^{*}\right)^{2}}<0$ (Lemma 1) we know that the $q^{*}$ for which $\frac{\partial q_{i}^{*}}{\partial q^{*}}=1$, is also the $q^{*}$ for which $q_{i}^{*}-q^{*}$ is maximized. Hence, if at this $q^{*}$ it holds that $q_{i}^{*} \ngtr q^{*}$, then this will hold for any $q^{*}$, meaning that there are no interior equilibria.

- Suppose not (part 2): at the value of $q^{*}$ for which $\frac{\partial q_{i}^{*}}{\partial q^{*}}=1$, we have $q_{i}^{*}>q^{*}$, but this $q^{*} \notin[0,1]$. Then there could not be two interior equilibria, since (again by Lemma 1) one crossing occurs below this $q^{*}$ and the other above.

These points prove necessity of the conditions. Sufficiency follows from the fact that by Proposition 1, Cases I, II and III are the only possible constellations. When $q_{i}^{*}>q^{*}$ for some $q^{*} \in[0,1]$ Case I is excluded: by $q_{i}^{*}<0$ for $q^{*}=0$ there necessarily is a crossing. And by $q_{i}^{*}<1$ for $q^{*}=1$, Case II is also excluded.

Algebraically, the conditions that "at the value of $q^{*}$ for which $\frac{\partial q_{i}^{*}}{\partial q^{*}}=1$, we have $q_{i}^{*}>q^{*}$, and that value of $q^{*}$ must be $\in[0,1]^{\prime \prime}$ can be written as follows. First, from equation (9)

$$
\begin{aligned}
\frac{\partial q_{i}^{*}}{\partial q^{*}} & =1 \Leftrightarrow \\
\frac{1}{2 c} \frac{(1-\rho)^{2} d}{\left[q^{*}(1-\rho)+\rho\right]^{2}} & =1 \Leftrightarrow \\
q^{*} & =\sqrt{\frac{d}{2 c}}-\frac{\rho}{(1-\rho)}
\end{aligned}
$$

Hence, "the value of $q^{*}$ must be $\in[0,1]$ " can be written to

$$
\left(\sqrt{\frac{d}{2 c}}-\frac{\rho}{1-\rho}\right) \in[0,1]
$$


and "at the value of $q^{*}$ for which $\frac{\partial q_{i}^{*}}{\partial q^{*}}=1$, we have $q_{i}^{*}>q^{*}$ " becomes, from equation (8):

$$
\begin{aligned}
\frac{1}{2 c}\left[R-d\left(\frac{1-\rho}{\left[\sqrt{\frac{d}{2 c}}-\frac{\rho}{1-\rho}\right](1-\rho)+\rho}+\rho x\right)\right] & >\sqrt{\frac{d}{2 c}}-\frac{\rho}{1-\rho} \Leftrightarrow \\
\frac{1}{2 c}\left[R-d\left(\sqrt{\frac{2 c}{d}}+\rho x\right)\right] & >\sqrt{\frac{d}{2 c}}-\frac{\rho}{1-\rho} \Leftrightarrow \\
R-\sqrt{2 c d}-\rho x d & >\sqrt{2 c d}-\frac{2 c \rho}{1-\rho} \Leftrightarrow \\
R & >2 \sqrt{2 c d}+\rho x d-\frac{2 c \rho}{1-\rho}
\end{aligned}
$$

We have now proven that

$$
\begin{aligned}
& \text { Case II } \Leftrightarrow R>2 c+d(1+\rho(x-1)) \\
& R \leq 2 c+d(1+\rho(x-1)) \\
& \text { Case III } \Leftrightarrow \wedge R>2 \sqrt{2 c d}+\rho x d-\frac{2 c \rho}{1-\rho} \\
& \wedge\left(\sqrt{\frac{d}{2 c}}-\frac{\rho}{1-\rho}\right) \in[0,1]
\end{aligned}
$$

Thus, by Proposition 1, the remaining parameterizations lead to Case I. Formally:

$$
\text { Case I } \Leftrightarrow \begin{array}{ll}
R \leq 2 c+d(1+\rho(x-1)) \\
\wedge\left[\left(R \leq 2 \sqrt{2 c d}+\rho x d-\frac{2 c \rho}{1-\rho}\right) \vee\left(\left(\sqrt{\frac{d}{2 c}}-\frac{\rho}{1-\rho}\right) \notin[0,1]\right)\right]
\end{array}
$$




\section{References}

Acharya, Viral V., and Tanju Yorulmazer, 2007, "Too Many To Fail - An Analysis of TimeInconsistency in Bank Closure Policies," Journal of Financial Intermediation, Vol. 16, pp. 1-31.

Acharya, Viral V., 2009, "A Theory of Systemic Risk and Design of Prudential Bank Regulation," Journal of Financial Stability, Vol. 5, pp. 224-255.

Acharya, Viral V., Hamid Mehran, and Anjan V. Thakor, 2010, "Caught Between Scylla and Charybdis? Regulating Bank Leverage When There Is Rent Seeking and Risk Shifting," Federal Reserve Bank of New York Staff Reports No. 469 (New York: Federal Reserve Bank).

Acharya, Viral V., Denis Gromb, and Tanju Yorulmazer, 2012, "Imperfect Competition in the Interbank Market for Liquidity as a Rationale for Central Banking," American Economic Journal: Macroeconomics, Vol. 4(2), pp. 184-217.

Acharya, Viral V., Lasse H. Pedersen, Thomas Philippon, and Matthew P. Richardson, 2012, "Measuring Systemic Risk," CEPR Discussion Paper No. 8824.

Adrian, Tobias, and Markus K. Brunnermeier, 2011, "CoVaR," NBER Working Paper No. 17454 (Cambridge, MA: National Bureau of Economic Research).

Afonso, Gara, Anna Kovner, and Antoinette Schoar, 2013, "Trading Partners in the Interbank Lending Market," Federal Reserve Bank of New York Staff Report No. 620 (New York: Federal Reserve Bank).

Affinito, Massimiliano, 2012, "Do Interbank Customer Relationships Exist? And How Did They Function in the Crisis? Learning from Italy," Journal of Banking and Finance, Vol. 36(12), pp. 3163-3184.

Agur, Itai and Sunil Sharma, 2013, "Rules, Discretion, and Macro-Prudential Policy," IMF Working Paper No. 13/65 (Washington: International Monetary Fund).

Aikman, David, Piergiorgio Alessandri, Bruno Eklund, Prasanna Gai, Sujit Kapadia, Elizabeth Martin, Nada Mora, Gabriel Sterne, and Matthew Willison, 2009, "Funding Liquidity Risk in a Quantitative Model of Systemic Stability," Bank of England Working Paper No. 372 (London: Bank of England).

Akerlof, George, 1970, "The Market for "Lemons": Quality Uncertainty and the Market Mechanism," Quarterly Journal of Economics, Vol. 84(3), pp. 488-500.

Allen, Franklin, and Douglas Gale, 2000, "Financial Contagion," Journal of Political Economy, Vol. 108, pp. 1-33.

Allen, Franklin, Ana Babus, and Elena Carletti, 2009, "Financial Crises: Theory and Evidence," Annual Review of Financial Economics, Vol. 1, pp. 97-116. 
Allen, Franklin, and Ana Babus, 2010, "Networks in Finance," In The Network Challenge, edited by Paul K. Kleindorfer and Yoram Wind (Prentice Hall: New Jersey).

Altman, Edward I., and Vellore M. Kishmore, 1996, "Almost Everything You Wanted To Know About Recoveries on Defaulted Bonds," Financial Analysts Journal, pp. 56-62.

Anand, Kartik, Prasanna Gai, and Matteo Marsili, 2012, "Rollover Risk, Network Structure and Systemic Financial Crises," Journal of Economic Dynamics and Control, Vol. 36(8), pp. 1088-1100.

Arnold, Bruce, Claudio Borio, Luci Ellis, and Fariborz Moshirian, 2012. "Systemic Risk, Macroprudential Policy Frameworks, Monitoring Financial Systems and the Evolution of Capital Adequacy," Journal of Banking and Finance, Vol. 36, pp. 3125-3132.

Battiston, Stefano, Domenico D. Gatti, Mauro Gallegatti, Bruce C. Greenwald, and Joseph E. Stiglitz, 2012, "Liaisons Dangereuses: Increasing Connectivity, Risk Sharing, and Systemic Risk," Journal of Economic Dynamics and Control, Vol. 36(8), pp. 11211141.

Bhattacharya, Sudipto, and Douglas Gale, 1987, "Preference Shocks, Liquidity and Central Bank Policy," In New Approaches to Monetary Economics, edited by William A. Barnett and Kenneth J. Singleton (Cambridge: Cambridge University Press).

Bank for International Settlements, 2010, "Basel III: International Framework for Liquidity Risk Measurement, Standards and Monitoring," Basel Committee on Banking Supervision Policy Paper No. 188 (Basel: Bank for International Settlements).

Bisias, Dimitrios, Mark Flood, Andrew W. Lo and Stavros Valavanis, 2012, "A Survey of Systemic Risk Analytics," US Treasury, Office of Financial Research Working Paper No. 0001 (Washington, DC: US Department of the Treasury).

Blinder, Alan S., Michael Ehrmann, Marcel Fratzscher, Jakob de Haan, and David-Jan Jansen, 2008, "Central Bank Communication and Monetary Policy: A Survey of Theory and Evidence," Journal of Economic Literature, Vol. 46(4), pp. 910-945.

Boissay, Frederic, 2011, "Financial Imbalances and Financial Fragility," ECB Working Paper No. 573 (Frankfurt: European Central Bank).

Borio, Claudio, 2014, "The Financial Cycle and Macroeconomics: What Have We Learnt," Journal of Banking and Finance, in press.

Brunnermeier, Markus K., 2009, "Deciphering the Liquidity and Credit Crunch 2007-2008," Journal of Economic Perspectives, Vol. 23, pp. 77-100.

Brunnermeier, Markus K., Andrew Crockett, Charles Goodhart, Avinash D. Persaud and Hyun Song Shin, 2009, The Fundamental Principles of Financial Regulation, Geneva Reports on the World Economy 11 (Geneva).

C)International Monetary Fund. Not for Redistribution 
Castioglionesi, Fabio, and Wolf Wagner, 2013, "On the Efficiency of Bilateral Interbank Insurance," Journal of Financial Intermediation, Vol. 22, pp. 177-200.

Cocco, João F., Francisco J. Gomes, and Nuno C. Martins, 2009, "Lending Relationships in the Interbank Market," Journal of Financial Intermediation, Vol. 18, pp. 24-48.

Claessens, Stijn, Giovanni Dell'Ariccia, Deniz Igan, and Luc Laeven, 2010, "Lessons and Policy Implications from the Global Financial Crisis," IMF Working Paper No. 10/44 (Washington, DC: International Monetary Fund).

De Socio, Antonio, 2013, "The Interbank Market After the Financial Turmoil: Squeezing Liquidity in a "Lemons Market" or Asking Liquidity "On Tap"," Journal of Banking and Finance, Vol. 37, pp. 1340-1358.

Diamond, Douglas, and Philip H. Dybvig, 1983, "Bank Runs, Deposit Insurance, and Liquidity," Journal of Political Economy, Vol. 91, pp. 401-419.

Diamond, Douglas W., and Raghuram G. Rajan, 2009, "The Credit Crisis: Conjectures about Causes and Remedies," American Economic Review, Papers and Proceedings, pp. 606-610.

Dinger, Valeriya, and Jürgen von Hagen, 2009, "Does Interbank Borrowing Reduce Bank Risk?" Journal of Money, Credit and Banking, Vol. 41(2-3), pp. 491-506.

Eichberger, Jürgen, and Martin Summer, 2005. "Bank Capital, Liquidity, and Systemic Risk," Journal of the European Economic Association, Vol. 3(2-3), pp. 547-555.

Eisenschmidt, Jens, and Jens Tapking, 2009, "Liquidity Risk Premia in Unsecured Interbank Money Markets," ECB Working Paper No. 1025 (Frankfurt: European Central Bank).

Ennis, Huberto M., and John A. Weinberg, 2013, "Over-the-Counter Loans, Adverse Selection, and Stigma in the Interbank Market," Review of Economic Dynamics, Vol. 16, pp. 601-616.

Fecht, Falko, Hans Peter Grüner, and Philipp Hartmann, 2012, "Financial Integration, Specialization, and Systemic Risk," Journal of International Economics, Vol. 88(1), pp. $150-161$.

Fecht, Falko, Kjell G. Nyborg, and Jörg Rocholl, 2011, "The Price of Liquidity: The Effects of Market Conditions and Bank Characteristics," Journal of Financial Economics, Vol. 102(2), pp. 344-362.

Flannery, Mark J., 1996, "Financial Crises, Payment Systems Problems, and Discount Window Lending," Journal of Money, Credit and Banking, Vol. 28(4 - Part 2), pp. 804-824.

Freixas, Xavier, Bruno M. Parigi and Jean-Charles Rochet, 2000, "Systemic Risk, Interbank Relations, and Liquidity Provision by the Central Bank," Journal of Money, Credit and Banking, Vol. 32(3 - part 2), pp. 611-638. 
Freixas, Xavier, Bruno M. Parigi and Jean-Charles Rochet, 2004, "The Lender of Last Resort: A 21st Century Approach," Journal of the European Economic Association, 2(6), pp. 1085-1115.

Freixas, Xavier, and Cornelia Holthausen, 2005, "Interbank Market Integration under Asymmetric Information," Review of Financial Studies, Vol. 18(2), pp. 459-490.

Freixas, Xavier, and José Jorge, 2008, "The Role of Interbank Markets in Monetary Policy: a Model with Rationing," Journal of Money, Credit and Banking, Vol. 40(6), pp. 1151-1176.

Freixas, Xavier, Antoine Martin, and David R. Skeie, 2011, "Bank Liquidity, Interbank Markets, and Monetary Policy," Review of Financial Studies, Vol. 24(8), pp. 26562692.

Furfine, Craig H., 2003, "Interbank Exposures: Quantifying the Risk of Contagion," Journal of Money, Credit and Banking, Vol. 35(1), pp. 111-128.

Galati, Gabriele, and Richhild Moessner, 2012, "Macroprudential Policy - A Literature Review," Journal of Economic Surveys, Vol. 27(5), pp. 846-878.

Garratt, Rodney J., Lavan Mahadeva, Katsiaryna Svirydzenka, 2014, "The Great Entanglement: The Contagious Capacity of the International Banking Network Just Before the 2008 Crisis," Journal of Banking and Finance, In Press.

Georg, Co-Pierre, 2013, "The Effect of the Interbank Network Structure on Contagion and Common Shocks," Journal of Banking and Finance, Vol. 37, pp. 2216-2228.

Glasserman, Paul, and H. Peyton Young, 2014, "How Likely Is Contagion in Financial Networks?" Journal of Banking and Finance, In Press.

Goldstein, Itay, and Ady Pauzner, 2005, "Demand-Deposit Contracts and the Probability of Bank Runs," Journal of Finance, Vol. 60(3), pp. 1293-1327.

Heider, Florian, and Marie Hoerova, 2009, "Interbank Lending, Credit-Risk Premia, and Collateral," International Journal of Central Banking, Vol. 5(4), pp. 5-43.

Heider, Florian, Marie Hoerova, and Cornelia Holthausen, 2009, "Liquidity Hoarding and Interbank Market Spreads: The Role of Counterparty Risk," ECB Working Paper No. 1126 (Frankfurt: European Central Bank).

Huang, Rocco, and Lev Ratnovski, 2011. "The Dark Side of Bank Wholesale Funding," Journal of Financial Intermediation, Vol. 20(2), pp. 248-263.

Ibragimov, Rustam, Dwight Jaffee, and Johan Walden, 2010, "Diversification Disasters," Journal of Financial Economics, Vol. 99, pp. 333-348.

Keeley, Michael C., 1990, "Deposit Insurance, Risk and Market Power in Banking," American Economic Review, Vol. 80(5), pp. 1183-1200. 
Liedorp, Franka R., L. Medema, Michael Koetter, Ruud H. Koning, and Iman van Lelyveld, 2010, "Peer Monitoring or Contagion? Interbank Market Exposure and Bank Risk," De Nederlandsche Bank Working Paper No. 248 (Amsterdam: De Nederlandsche Bank).

Lim, Cheng Hoon, Alejo Costa, Torsten Wezel, Akira Otani, Francesco Columba, Mustafa Sayid, Xiaoyong Wu, and Piyabha Kongsamut, 2011, "Macroprudential Policy: What Instruments and How to Use Them? Lessons from Country Experiences," IMF Working Paper No. 11/238 (Washington: IMF).

Löffler, Gunter, and Peter Raupach, 2013, "Robustness and Informativeness of Systemic Risk Measures," Deutsche Bundesbank Working Paper No. 04/2013 (Frankfurt: Deutsche Bundesbank).

López-Espinosa, Germán, Antonio Moreno, Antonio Rubia, and Laura Valderrama, 2012, "Short-Term Wholesale Funding and Systemic Risk: A Global CoVaR Approach," Journal of Banking and Finance, Vol. 36, pp. 3150-3162.

Myers, Stewart C., and Nicholas S. Majluf, 1984, "Corporate Financing and Investment Decisions When Firms Have Information Investors Do Not Have," Journal of Financial Economics, Vol. 13, pp. 187-221.

Nier, Erlend W., Jing Yang, Tanju Yorulmazer, and Amadeo Alentorn, 2007, "Network Models and Financial Stability," Journal of Economic Dynamics and Control, Vol. 31, pp. 2033-2060.

Perotti, Enrico, Lev Ratnovski, and Razvan Vlahu, 2011, "Capital Regulation and Tail Risk," International Journal of Central Banking, Vol. 27, pp. 123-163.

Perotti, Enrico, and Javier Suarez, 2011, "A Pigouvian Approach to Liquidity Regulation," International Journal of Central Banking, Vol. 7(4), pp. 3-41.

Ratnovski, Lev, 2013, "Liquidity and Transparency in Bank Risk Management," Journal of Financial Intermediation, Vol. 22(3), pp. 422-439.

Rochet, Jean-Charles, and Jean Tirole, 1996, "Interbank Lending and Systemic Risk," Journal of Money, Credit and Banking, Vol. 28(4 - Part 2), pp. 733-762.

Rochet, Jean-Charles, and Xavier Vives, 2004, "Coordination Failures and the Lender of Last Resort: Was Bagehot Right After All?" Journal of the European Economic Association, Vol. 2(6), pp. 1116-1147.

Rosser, J. Barkley, Jr., 1999, "On the Complexities of Complex Economic Dynamics," Journal of Economic Perspectives, Vol. 13(4), pp. 169-192.

Shleifer, Andrei, and Robert W. Vishny, 2011, "Fire Sales in Finance and Macroeconomics," Journal of Economic Perspectives, Vol. 25(1), pp. 29-48.

Stahl, Dale O., 1988, "Bertrand Competition for Inputs and Walrasian Outcomes," American Economic Review, Vol. 78(1), pp. 189-201.

CInternational Monetary Fund. Not for Redistribution 
Thakor, Anjan V., 1996, "Capital Requirements, Monetary Policy, and Aggregate Bank Lending: Theory and Empirical Evidence," Journal of Finance, Vol. 51, pp. 279-324.

Upper, Christian, 2011, "Simulation Methods to Assess the Danger of Contagion in Interbank Markets," Journal of Financial Stability, Vol. 7(3), pp. 111-125.

Wagner, Wolf, 2010, "Diversification at Financial Institutions and Systemic Crises," Journal of Financial Intermediation, Vol. 19, pp. 373-386.

Zhou, Chen, 2013, "The Impact of Imposing Capital Requirements on Systemic Risk," Journal of Financial Stability, Vol. 9(3), pp. 320-329. 